Rogoff, M. H. (1958). J. gen. Microbiol. 19, 330-339

\title{
An Aromatic Intermediate in the Bacterial Oxidation of Quinic Acid
}

\author{
By M. H. ROGOFF \\ Bureau of Mines, Region V, U.S. Department of the Interior, \\ Pittsburgh 13, Pennsylvania, U.S.A.
}

SUMMARY: Strains of Pseudomonas and Achromobacter spp. isolated from soil, utilized quinic acid as a sole source of carbon. Protocatechuic acid was produced as an intermediate in this oxidation. Protocatechuic acid was also produced in the course of oxidation of $p$-hydroxybenzoic acid by these organisms. Sequential induction experiments indicate that $p$-hydroxybenzoic acid is not an intermediate in quinic acid oxidation by the organisms used.

Aromatic compounds are produced by micro-organisms in the synthesis of the aromatic constituents of their own cell substance. Apart from these anabolic syntheses certain micro-organisms produce aromatic metabolic products in the course of oxidative assimilation of non-aromatic materials. One such product is 6-hydroxy-2-methyl-benzoic acid, produced by Penicillium griseofulvum Dierckx from acetate (Birch, Massy-Westropp \& Moye, 1955). Many of the anthraquinone pigments produced by moulds are in this category. Emmerling \& Abderhalden (1903) showed that quinic acid (1:3:4:5-tetrahydroxycyclohexanecarboxylic acid) was attacked by an organism named Micrococcus chinicus, giving rise to protocatechuic acid. Butkewitsch (1924) reported that certain moulds produced protocatechuic acid and catechol from quinic acid; the catechol was assumed to have arisen from protocatechuic acid. This, however, is not in keeping with current concepts of protocatechuic acid oxidation (Umbreit, 1952; Evans, 1956).

The present work was begun to determine whether protocatechuic acid produced from quinic acid represents an intermediate in quinic acid oxidation or a metabolic end product, to determine the quantitative aspects of the conversion, and if possible to determine other aromatic intermediates.

\section{METHODS}

Pure cultures of quinic acid-oxidizing bacteria and fungi were isolated from soil by using an enrichment technique. Enrichments and fermentations were carried out, and stock cultures maintained, on a medium of the following composition (g.): quinic acid, 10.00; $\mathrm{NH}_{4} \mathrm{NO}_{3}, 4.00 ; \mathrm{MgSO}_{4}, 0.50 ; \mathrm{MnCl}_{2}$. $4 \mathrm{H}_{2} \mathrm{O}, 0 \cdot 10 ; \mathrm{FeCl}_{2} .4 \mathrm{H}_{2} \mathrm{O}, 0.05 ; \mathrm{K}_{2} \mathrm{HPO}_{4}, 1 \cdot 0 ; \mathrm{CaCO}_{3}, 2.0$; in distilled water, 11. The medium was prepared as two double-strength solutions, one containing only the $\mathrm{K}_{2} \mathrm{HPO}_{4}$. The quinic acid was dissolved in the phosphate solution and the $\mathrm{pH}$ value adjusted to $7 \cdot 4$ with $10 \%(\mathrm{w} / \mathrm{v}) \mathrm{KOH}$. The two solutions were then mixed and sterilized at $121^{\circ}$ for 20 min. When a solid medium was 
desired agar was added to $1.5 \%(w / v)$. The final $\mathrm{pH}$ value of the medium was $\mathbf{7 \cdot 2} \pm \mathbf{0 \cdot 0 5}$.

Organisms for manometric experiments were grown on mineral salts agar containing $0 \cdot 3 \%(w / v)$ of the appropriate carbon source. Six Kolle flasks, each containing $50 \mathrm{ml}$. of agar medium, were inoculated with $1.0 \mathrm{ml}$. each of a $24 \mathrm{hr}$. liquid culture of the organism used. After $24 \mathrm{hr}$. of incubation at room temperature, the growth in each flask was washed off with $20 \mathrm{ml}$. M/25

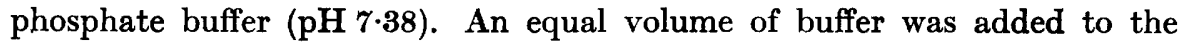
pooled washings, the organisms deposited by centrifugation at $5^{\circ}$, and washed twice in buffer and resuspended in $15 \mathrm{ml}$. buffer. Before use, dry-weight determinations of organisms in the suspensions were made and the suspensions adjusted to contain $1.0 \mathrm{mg}$. bacterial- $\mathrm{N} / \mathrm{ml}$.

The Warburg apparatus was used in the conventional manner to measure oxygen uptake (Umbreit, Burris \& Stauffer, 1957). Each vessel was made up with $1.0 \mathrm{ml}$. buffer containing $3 \mu$ mole of substrate in the sidearm, $0.15 \mathrm{ml}$. of

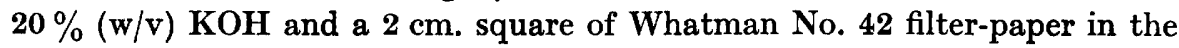
centre well, and $1.0 \mathrm{ml}$. of cell suspension and enough buffer to bring the volume to $3.0 \mathrm{ml}$. in the flask. All manometric experiments were run at $30^{\circ}$.

Analyses of ultraviolet (u.v.) absorption were made in a Cary Model 11 ultraviolet spectrophotometer, with buffer of $95 \%(v / v)$ ethanol in water as solvent. Quantitative determination of protocatechuic acid was made by measurement of absorption at $290 \mathrm{~m} \mu$, or $293 \mathrm{~m} \mu$ if the sample was acidified to reduce scattering (Fig. 1). Concentrations were calculated from a standard curve prepared by plotting D 293 against concentration of protocatechuic acid in the range $0.005-0.05 \mathrm{mg} . / \mathrm{ml}$., or by baseline calculations made by the method of Wright (1941). A check on the identity of the compound being determined was made with the 257 and $293 \mathrm{~m} \mu$ readings which bear the constant relationship D 257/D 293 =1.95 \pm 0.05 for protocatechuic acid. Infrared analyses were made in a Perkin-Elmer Model 21 double-beam infrared spectrophotometer. Samples were prepared for analysis as potassium bromide pellets.

\section{RESULTS}

\section{Isolation of cultures}

Flasks (1 l. Erlenmeyer) containing $200 \mathrm{ml}$. of medium were inoculated for enrichment of the desired organisms with $1 \mathrm{~g}$. each of a garden soil. After $48 \mathrm{hr}$. of incubation at room temperature, a heavy growth of micro-organisms, predominantly fungal, was noted in all flasks. Subcultures were made by streaking plates of quinic acid agar with a loopful of liquid culture. Selection and subculture on the same medium yielded over 40 pure cultures capable of using quinic acid as a sole carbon source. About 2/5 of the cultures were moulds of the genera Penicillium and Aspergillus. The bacteria isolated were Gram-negative rods, except for a few Gram-variable irregularly staining forms tentatively identified as Corynebacterium spp. The bacteria used were of three types, and a representative culture of each type was used in these studies. 
The characteristics of the representative cultures chosen for these studies are summarized in Table 1.

Cultures A-5 and D-19 are members of the genus Pseudomonas. A-5 closely resembles the type species $P$. aeruginosa, exuding a marked odour of trimethylamine, and is so designated; D-19 is not identical with any of the species reported in Bergey's Manual (1948). Culture E-20 is apparently a member of the genus Achromobacter, and resembles the aromatic hydrocarbonattacking $A$. cycloclastes.

Table 1. Morphological and biochemical characteristics of bacteria capable of using quinic acid as sole carbon and energy source

\begin{tabular}{|c|c|c|c|}
\hline \multirow[b]{2}{*}{ Characteristic } & \multicolumn{3}{|c|}{ Isolate } \\
\hline & A5 & D19 & E20 \\
\hline $\begin{array}{l}\text { Growth on quinate } \\
\text { liquid medium }\end{array}$ & $\begin{array}{l}\text { Green top, deep purple } \\
\text { bottom }\end{array}$ & $\begin{array}{l}\text { Purple throughout } \\
\text { tube }\end{array}$ & $\begin{array}{l}\text { Pale faintly fluor- } \\
\text { escent bluish colou }\end{array}$ \\
\hline Gram reaction & $\begin{array}{l}\text { Gram-negative very } \\
\text { small rods }\end{array}$ & $\begin{array}{l}\text { Gram-negative small } \\
\text { rods }\end{array}$ & Gram-negative rods \\
\hline $\begin{array}{l}\text { Colonies on nutrient } \\
\text { agar }\end{array}$ & $\begin{array}{l}3 \mathrm{~mm} \text {, irregular, } \\
\text { smooth centre, } \\
\text { radiate edge, con- } \\
\text { vex, translucent, } \\
\text { agar pinkish }\end{array}$ & $\begin{array}{l}\text { Small, irregular, } \\
\text { rough, butyrous, } \\
\text { convex, irridescent }\end{array}$ & $\begin{array}{l}\text { Smooth, round, } \\
\text { convex, white, } \\
\text { opaque }\end{array}$ \\
\hline Nutrient agar slope & $\begin{array}{l}\text { Spreading, smooth, } \\
\text { radiate edge, } \\
\text { glistening, agar pink }\end{array}$ & $\begin{array}{l}\text { Spreading, rough, } \\
\text { irridescent }\end{array}$ & $\begin{array}{l}\text { Thick, smooth, } \\
\text { white, glistening, } \\
\text { fliform }\end{array}$ \\
\hline Nutrient broth & $\begin{array}{l}\text { Moderate turbidity, } \\
\text { pellicle }\end{array}$ & $\begin{array}{l}\text { Moderate turbidity, } \\
\text { pellicle }\end{array}$ & $\begin{array}{l}\text { Heavy turbidity, } \\
\text { pellicle }\end{array}$ \\
\hline Motility & + & + & + \\
\hline Gelatin liquefaction & + & - & - \\
\hline Nitrate reduction & $\rightarrow \mathrm{NO}_{2}$ & - & $\rightarrow \mathrm{N}_{2}$ \\
\hline Litmus milk & $\begin{array}{l}\text { Peptonization, slow } \\
\text { reduction, blue-grey } \\
\text { pellicle }\end{array}$ & No action & No action \\
\hline $\begin{array}{l}\text { Glucose, sucrose, } \\
\text { lactose broth }\end{array}$ & No acid or gas & No acid or gas & No acid or gas \\
\hline Asparagine broth & $\begin{array}{l}\text { Pale-green soluble } \\
\text { pigment }\end{array}$ & $\begin{array}{l}\text { Pale yellowish green } \\
\text { soluble pigment }\end{array}$ & No pigment \\
\hline
\end{tabular}

\section{Protocatechuic acid formation from quinic acid}

Each culture produced a characteristic coloration in deep tubes of quinic acid liquid medium (Table 1). Ferric chloride tests (Soloway \& Rosen, 1953) with an authentic sample of protocatechuic acid gave a deep green colour. Tests of the reaction of ferrous chloride with protocatechuic acid showed that the acid gave a purple colour with ferrous ion; the test medium in the tubes was prepared with ferrous chloride. The characteristic two-colour appearance of the tubes of culture A-5 could be duplicated in a solution of protocatechuic acid and ferrous chloride, the top of the tube becoming green on standing owing to oxidation of ferrous ion to the ferric state. Samples taken from 
$48 \mathrm{hr}$. liquid medium tube cultures gave a green colour with ferric chloride, regardless of purple coloration in the tube.

In shaken flask experiments, $400 \mathrm{ml}$. portions of quinic acid liquid medium in $2800 \mathrm{ml}$. Fernbach flasks were inoculated with $25 \mathrm{ml}$. of $48 \mathrm{hr}$. liquid cultures of the organisms tested. After 24-48 hr. of shaking at room temperature the culture fluid took on a violet to purple colour, which persisted for an additional 18-24 hr. period. Samples of culture fluid taken during the period of colour formation gave green a colour with ferric chloride and had a u.v. absorption spectrum identical with that of an authentic sample of protocatechuic acid. Some scattering occasionally interfered with the spectrum but was dissipated by the addition of a drop of conc. $\mathrm{HCl}$ diluted with an equal volume of water to the absorption cell (Fig. 1). Quinic acid gave no interfering absorption in the ultraviolet region.

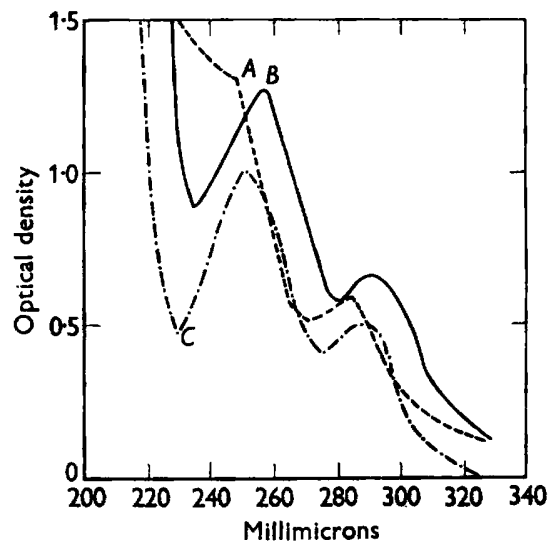

Fig. 1

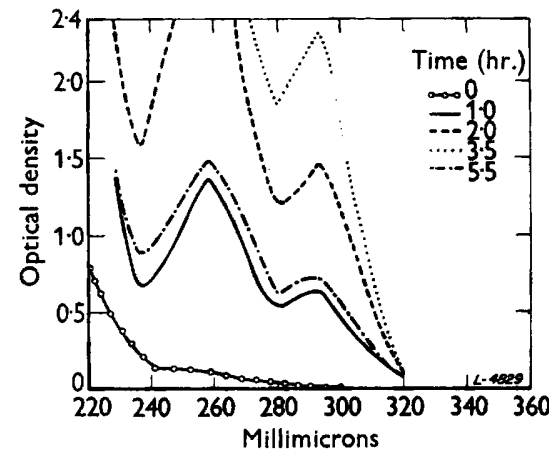

Fig. 2

Fig. 1. Ultraviolet absorption spectrum of protocatechuic acid in treated and untreated quinic acid medium cultures.

Fig. 2. Ultraviolet absorption spectra of a washed suspension (organism A-5) producing protocatechuic acid from quinic acid.

The production of protocatechuic acid by a washed suspension of organisms was determined as follows. Quinic acid (250 mg.) was dissolved in $25 \mathrm{ml}$. of

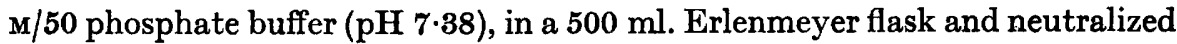
with $4 \%(w / v)$ aqueous KOH. One ml. of a solution containing $2.5 \mathrm{mg}$. $\mathrm{MgSO}_{4} / \mathrm{ml}$., and $10 \mathrm{ml}$. of a washed suspension of organisms equivalent to $1.0 \mathrm{mg}$. bacterial $-\mathrm{N} / \mathrm{ml}$. were then added, and the volume was made up to $50 \mathrm{ml}$. with buffer. The final concentrations in this system were thus (mg./ml.): quinic acid, $5.0 ; \mathrm{MgSO}_{4}, 0.05$; bacterial-N, 0.02. The flasks were prepared in duplicate and placed on the shaker at room temperature. Samples were taken at $30 \mathrm{~min}$. intervals for ferric chloride tests and u.v. absorption spectra. Samples for u.v. spectra consisted of $1.0 \mathrm{ml}$. samples added to an equal volume of $1.2 \%(w / v)$ trichloroacetic acid. The samples were then diluted to $10.0 \mathrm{ml}$., centrifuged for $15 \mathrm{~min}$., decanted, and diluted with distilled water as 
required for determination of their u.v. spectra, illustrated in Fig. 2. Although absorption above $250 \mathrm{~m} \mu$ by trichloroacetic acid was negligible at the concentrations used (D 257 $=0.03, \mathrm{D} 293=0.01$ ), the zero time reading at $293 \mathrm{~m} \mu$ was subtracted in concentration determinations. The blank cell contained distilled water. The quantitative estimation of protocatechuic acid production in the same experiment is given in Fig. 3.

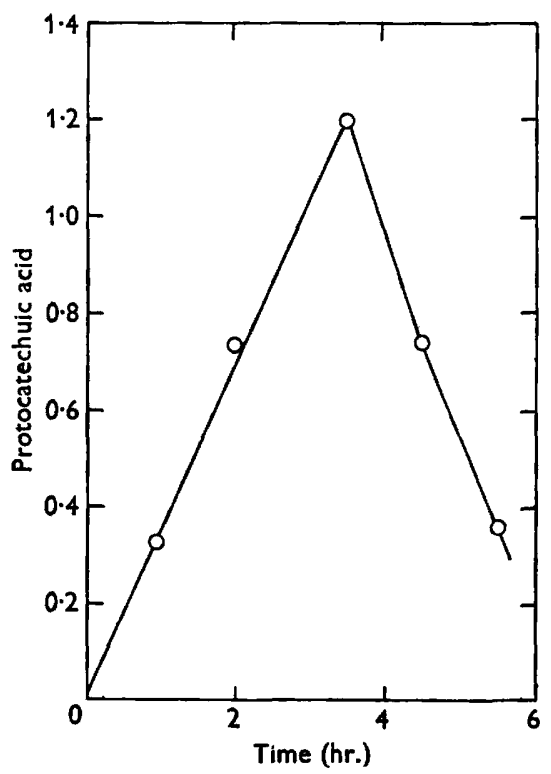

Fig. 3. Production of protocatechuic acid from quinic acid $(5 \cdot 0 \mathrm{mg} \cdot / \mathrm{ml}$.) by a washed suspension of organism A-5.

\section{Identification of protocatechuic acid and production from p-hydroxybenzoic acid}

In shaken-flask experiments with $0.3 \%(w / v) p$-hydroxybenzoic acid as carbon source, no intermediate was apparent by ferric chloride test or u.v. spectrum during incubation for $96 \mathrm{hr}$. In other experiments $150 \mathrm{ml}$. volumes of the same medium in $300 \mathrm{ml}$. Erlenmeyer flasks were inoculated with $1.0 \mathrm{ml}$. of $p$-hydroxybenzoic acid-grown liquid cultures of the three test organisms, and incubated at room temperature without shaking. Samples drawn from these flasks between 48 and $72 \mathrm{hr}$. of incubation gave a pale green colour with ferric chloride. The u.v. spectra of samples removed during the same period did not reveal the presence of protocatechuic acid. Protocatechuic acid was not identified in this case by u.v. spectra alone since $p$-hydroxybenzoic acid absorbs much more strongly in the u.v. region than protocatechuic acid; its main absorption maximum is at $255 \mathrm{~m} \mu$, and masks the protocatechuic acid maximum at $257 \mathrm{~m} \mu$.

Further experiments were carried out with triplicate sets of flasks for each test organism. One flask of each triplicate set was used at 48,60 and $72 \mathrm{hr}$., respectively. Metabolism was stopped by heating the cultures to $78^{\circ}$ for 


\section{Quinic acid oxidation}

$10 \mathrm{~min}$. After $72 \mathrm{hr}$. the three flasks from each test organism set were pooled and centrifuged. The supernatant fluids were acidified and extracted with $3 \times 25 \mathrm{ml}$. portions of ether. The ether extracts were extracted with $2 \times 20 \mathrm{ml}$. portions of $10 \%(w / v) \mathrm{NaHCO}_{3}$. The aqueous phases were acidified with hydrochloric acid (1 vol. conc. $\mathrm{HCl}+1$ vol. water) and extracted with $2 \times 25 \mathrm{ml}$. portions of ether and the ether then removed by warming under a stream of warm nitrogen. Approximately $750 \mathrm{mg}$. of material was recovered in this manner from a triplicate set of flasks.

Ultraviolet spectra of the recovered material showed an absorption maximum at $293 \mathrm{~m} \mu$; the secondary maximum of protocatechuic acid appears at this wavelength. The main peak in these spectra was at $255 \mathrm{~m} \mu$, characteristic of $p$-hydroxybenzoic acid. By assigning the $293 \mathrm{~m} \mu$ peak to protocatechuic acid, calculation showed the material to contain approximately $4.0 \%$ protocatechuic acid. Infrared spectra of the materials did not reveal any bands other than those characteristic of $p$-hydroxybenzoic acid. Concentration of protocatechuic acid in this material was carried out by a differential solubility procedure. A $500 \mathrm{mg}$. portion of sample was treated with $3 \mathrm{ml}$. water and thoroughly mixed. The sample was centrifuged in the cold and the water removed by pipetting. The supernatant fluid was filtered, acidified with 1 drop of ' $1: 1 \mathrm{HCl}$ ' and extracted with two equal volumes of ether. The ether layer was removed and evaporated to dryness. One ml. of water was then added to the residue and the procedure repeated. The final residue was dissolved in $95 \%(\mathrm{v} / \mathrm{v})$ ethanol in water and the ultraviolet spectrum determined. Spectra on these samples showed a definite absorption maximum at $293 \mathrm{~m} \mu$, from which a ratio of $35 \%$ protocatechuic acid : 65 \% $p$-hydroxybenzoic acid was calculated; the actual values were $4.9 \mathrm{mg}$. $p$-hydroxybenzoic acid and $2 \cdot 64 \mathrm{mg}$. protocatechuic acid (these figures are for culture E-20 fermentation).

Infrared spectra of the enriched samples of material were used to establish the identity of protocatechuic acid as a component of it. Spectra of the pure compounds were determined. Bands characteristic of protocatechuic acid, and distinct from those of $p$-hydroxybenzoic acid, appear at $3 \cdot 1,6 \cdot 55,6 \cdot 9$, $7 \cdot 25,8 \cdot 95,10 \cdot 63,11 \cdot 27$ and $13 \cdot 48 \mu$. In the mixed samples distinct bands appeared at $3 \cdot 1,8.95,10 \cdot 63,11 \cdot 27$ and $13.48 \mu$; the 6.55 band appeared as a shoulder. The bands at 6.9 and $7 \cdot 25 \mu$ were distinguishable as extra absorption in these regions. The infrared spectra of the samples were qualitatively identical with that of mixture of $35 \mathrm{mg}$. of authentic protocatechuic acid with $65 \mathrm{mg}$. of $p$-hydroxybenzoic acid.

\section{Manometric experiments}

A series of experiments was conducted with organisms grown on media containing, respectively, quinic, protocatechuic and $p$-hydroxybenzoic acid, and the same acids as substrates. Non-induced organisms grown with asparagine as sole $\mathrm{C}$ source showed a definite lag period with the above compounds as substrates. The results of the experiments with culture A-5 are summarized 
in Figs. 4-6; qualitatively equivalent results were obtained with cultures D-19 and E-20.

\section{Growth experiments}

Tubes of quinic acid liquid medium were prepared, and tubes containing the same basal medium but with $p$-hydroxybenzoic or $m$-hydroxybenzoic acid as a source of carbon. Tubes of each medium were inoculated with one drop of a $24 \mathrm{hr}$. quinic acid liquid culture of each organism. All three organisms showed visible growth in the quinic and $p$-hydroxybenzoic acid media and subcultures showed continued growth through five transfers. No growth with $m$-hydroxybenzoic acid as carbon source was observed in any instance.

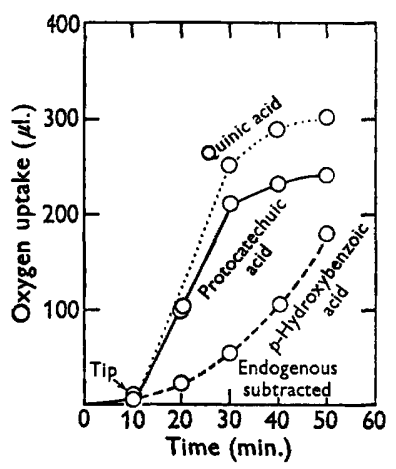

Fig. 4

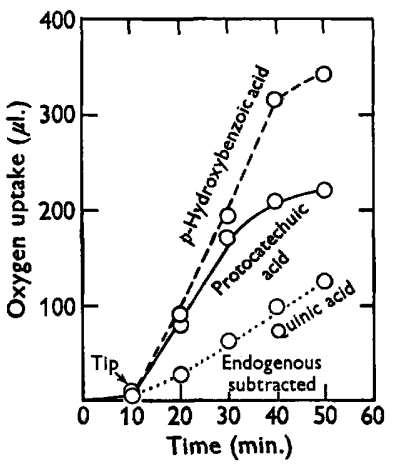

Fig. 5

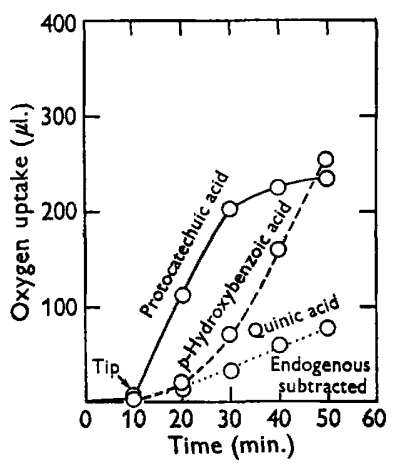

Fig. 6

Fig. 4. Warburg study-resting cells of quinic acid grown culture A-5. Substrate concentration $=3 \mu$ mole.

Fig. 5. Warburg study-resting cells of $p$-hydroxybenzoic acid grown culture A-5. Substrate concentration $=\mathbf{3} \mu$ mole.

Fig. 6. Warburg study-resting cells of protocatechuic acid grown culture A-5. Substrate concentration $=\mathbf{3} \mu$ mole.

\section{DISCUSSION}

Culture A-5 used in these studies closely resembles and may be considered a strain of Pseudomonas aeruginosa. Culture D-19, although bearing some resemblance to the hydrocarbon-attacking $P$. arvilla; is not identical with that organism; it apparently belongs to the non-proteolytic group of aromatic ring-attacking pseudomonads. Culture E-20 differs from Achromobacter cycloclastes in that it did not produce a pale buff pigment on agar slopes. It is doubtful whether species assignment for cultures D-19 and E-20 should be made on the basis of present data.

The production of protocatechuic acid from quinic acid has been confirmed, the conversion being carried out by a wider range of bacteria than hitherto reported. Protocatechuic acid appears as an intermediate in the oxidative pathway, as evidenced by its eventual disappearance from shaken-flask cultures and washed suspensions, and by the fact that quinic acid-induced organisms (Fig. 4) oxidize the compound with no lag period. Protocatechuic 
acid production may represent a slow step in the quinic acid oxidation path.

Since an aromatization pathway to $p$-hydroxybenzoic acid, proceeding through 5-dehydroquinic, 5-dehydroshikimic and skikimic acids was known (Davis, 1955, Fig. 7) and an oxidative pathway for $p$-hydroxybenzoic acid proceeding via protocatechuic acid was also known (Evans, 1956; Henderson, 1957), it was felt that $p$-hydroxybenzoic acid might also be an intermediate in quinic acid oxidation. Although $p$-hydroxybenzoic acid was readily attacked by the cultures tested, and it was demonstrated that protocatechuic acid is<smiles>CC1CCCC(O)(C(O)O)C1(O)C(=O)O</smiles><smiles>C=CCCCCCC</smiles><smiles>C=C=CC1CC(O)(C(=O)O)C[C@@H](C)C(=O)C1O</smiles>

5-Dehydroshikimic acid<smiles>C=C=CC1CC(C(=O)O)=CC(=O)C1O</smiles>

5-Dehydroquinic acid<smiles>O=C(O)C1=CC(O)C(O)C(O)C1</smiles><smiles>O=C(O)c1ccc(O)cc1</smiles>

Shikimic acid
$p$-Hydroxybenzoic acid

Fig. 7. Aromatization of quinic acid (after Davis, 1955).

indeed produced as an intermediate in $p$-hydroxybenzoic acid oxidation, the sequential induction experiments indicate that the compound is not an intermediate in quinic acid oxidation (Fig. 8); quinic acid-grown organisms showed a lag period before oxidizing $p$-hydroxybenzoic acid, but possessed the enzymes necessary to oxidize protocatechuic acid (Fig. 4). The reaction series is the result of induced enzyme formation since protocatechuic acid-grown organisms do not possess the enzymes necessary to oxidize quinic acid (Fig. 6), and asparagine-grown organisms do not possess the enzymes necessary to oxidize any of the compounds tested.

It is interesting that aromatization of quinic acid occurs in a catabolic pathway, preceding ring splitting and terminal oxidation. Such a pathway would, however, provide a rapid yield of energy from the dehydrations and dehydrogenations necessary to affect such a transformation. Although quinic acid does not lie directly on the known aromatization pathway (Davis, 1955), it is known that an enzyme (quinic dehydrogenase) present in Aerobacter converts quinic to 5-dehydroquinic acid (Davis \& Weiss, 1955). It is likely 


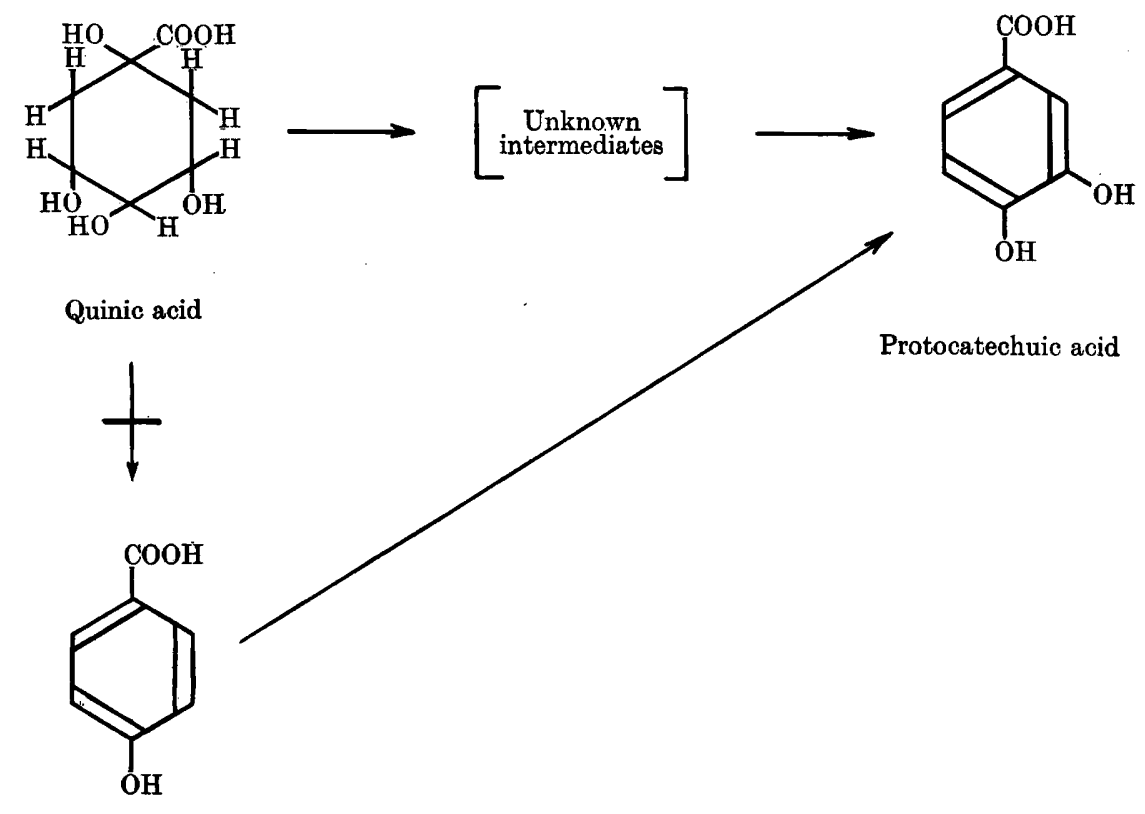

$p$-Hydroxybenzoic acid

Fig. 8. Protocatechuic acid formation from quinic acid and $p$-hydroxybenzoic acid.

that such an enzyme is present in the organisms under study here, although this has not been demonstrated. Aromatic intermediates which might arise from quinic acid before protocatechuic acid have thus far not been detected.

This paper is No. 4 in the series: Microbiology of Coal.

\section{REFERENCES}

Bergey's Manual of Determinative Bacteriology (1948). 6th ed. Ed., Breed, R. S., Murray, E. B. G. \& Hitchens, A. P. Baltimore: Williams and Wilkins.

Birch, A. J., Massy-Westropp, R. A. \& Moye, C. J. (1955). The biosynthesis of 6-hydroxy-2-methylbenzoic acid. Chem. \& Ind. 24, 683.

Butkewitsch, V. (1924). [Metabolism of quinic acid by fungi.] Biochem. Z. 145, 395.

Davis, B. D. (1955). Biosynthesis of the aromatic amino acids. In Amino Acid Metabolism, p. 799. Ed. McElroy, W. D. and Glass, B. Baltimore: The Johns Hopkins Press.

Davis, B. D. \& WeIss, U. (1955). Aromatic biosynthesis. VIII. 5-Dehydroquinic acid and quinic acid. Arch. exp. Path. Pharmak. 220, 1.

Emmerling, O. \& Abderhadden, E. (1903). As reported by Happold, F. C. (1950). The oxidation of aromatic rings by microorganisms in metabolism. Biochem. Soc. Symp. No. $5,85$.

Evans, W. C. (1956). Biochemistry of the oxidative metabolism of aromatic compounds by micro-organisms. Ann. Rep. chem. Soc. 53, 279.

Henderson, M. E. K. (1957). Metabolism of methoxylated aromatic compounds by soil fungi. J. gen. Microbiol. 16, 686. 
Soloway, S. \& Rosen, P. (1953). Differentiation of chelating from non-chelating phenols. Analyt. Chem. 25, 595.

Umbreit, W. W. (1952). Metabolic Maps. Minneapolis: Burgess Publishing Co.

Umbreit, W. W., Burris, R. H. \& Stauffer, J. F. (1957). Manometric Techniques and Tissue Metabolism, 3rd ed. Minneapolis: Burgess Publishing Co.

Wright, N. (1941). Application of infrared spectroscopy to industrial research. Industr. Engng Chem. (Anal.), 13, 1.

(Received 8 April 1958) 